\title{
PERANAN POLRI DALAM MENANGGULANGI TINDAK PIDANA PENCURIAN DENGAN KEKERASAN DI WILAYAH HUKUM POLRES PAYAKUMBUH
}

\author{
ANNY YUSERLINA \\ Sekolah Tinggi Ilmu Hukum Putri Maharaja Payakumbuh \\ Annyyuserlina87@gmail.com
}

\begin{abstract}
Crime in Indonesia in recent years has often been questioned by academics, the public and legal practitioners. One form of crime that has the highest frequency is theft. From there lies the big role of law enforcement officials in combating crime for the sake of creating public order. In general, the social problems that arise due to violent theft are felt to be very disruptive to people's lives, especially in the Payakumbuh Police jurisdiction. In essence, the problem is a shared responsibility. So the role of the Police in tackling criminal acts of theft with violence in the Legal Area of the Payakumbuh Police, but its role is not yet effective because in this case there are still found inhibiting factors to the role of the Police, so that the role of the Police is not effective
\end{abstract}

Keywords: Role of Police, Crime, Violent Theft

\begin{abstract}
Abstrak: Kejahatan di indonesia beberapa tahun terakhir ini sering kali dipersoalkan oleh kalangan akademisi, masyarakat maupun praktisi hukum. Salah satu bentuk kriminalitas yang mempunyai frekuensi tertinggi adalah tindak pidana pencurian. Dari situlah letak peran besar aparat penegak hukum dalam memberantas kejahatan demi terciptanya ketertiban umum. Pada garis besarnya masalah-masalah sosial yang timbul karena pencurian dengan kekerasan dirasakan sangat mengganggu kehidupan masyarakat khususnya di wilayah hukum Polres Payakumbuh. Problem tadi pada hakikatnya menjadi tanggung jawab bersama. Jadi peranan Polri dalam menanggulangi tindak pidana pencurian dengan kekerasan di Wilayh Hukum Polres Payakumbuh tetapi perananny belum efektif karena dalam hal ini masih ditemukan faktor-faktor penghambat terhadap peranan Polrinya, sehingga tidak terlaksananyaperanan Polri yang efektif.
\end{abstract}

Kata Kunci: Peranan Kepolisian, Tindak Pidana, Pencurian Dengan Kekerasan.

\section{A. Pendahuluan}

Indonesia adalah Negara yang berdasarkan atas hukum (Rechtstaat), hal ini dapat dilihat dalam Pasal 1 Ayat 3 Undang-Undang Dasar 1945. Hal ini menunjukkan bahwa Indonesia adalah negara hukum. Sebagai negara hukum, Indonesia menerima hukum sebagai ideologi untuk menciptakan ketertiban, keamanan, keadilan serta kesejahteraan bagi warga negaranya. Konsekuensi dari itu semua adalah bahwa hukum mengikat setiap tindakan yang dilakukan oleh warga negara Indonesia (C.S.T. Kansil, 1989: 346).

Oleh karena itu, hukum bekerja dengan cara memberikan petunjuk tentang tingkah laku dan karena itu pula hukum berupa norma. Hukum yang berupa norma dikenal dengan sebutan norma hukum, dimana hukum mengikatkan diri pada masyarakat sebagai tempat bekerjanya hukum tersebut. Unsur tindak pidana pencurian merupakan perbuatan pengambilan barang. Kata mengambil (wegnemen) merupakan 
dengan cara menggerakan tangan dan jari-jari, memegang barangnya, dan mengalihkannya ke tempat lain.

Akhir-akhir ini berbagai macam bentuk pencurian sudah demikian merebak dan meresahkan orang dalam kehidupan masyarakat sehari-hari. Bahkan sebagian masyarakat sudah cenderung terbiasa dan seolah-olah memandang pencurian dengan kekerasan tersebut merupakan kejahatan yang dianggap sebagai kebutuhan. Tindak pidana pencurian dalam bentuk pokok seperti yang diatur Pasal 362 KUHP terdiri dari atas unsur subjektif dan unsur objektif sebagai berikut:

a. Unsur subjektif: "Dengan maksud untuk menguasai benda tersebut secara melawan hukum".

b. Unsur objektif :

1. Hij atau barang siapa

2. Wegnemen atau mengambil

3. Eenig goed atau sesuai benda

4. Dat geheel of gedeeltelijk aan ander toebehoort atau yang sebagian atau seluruhnya kepunyaan orang lain.

Suatu tindak pidana pencurian yang diatur dalam Pasal 365 KUHP juga merupakan gequalificeerde diefstal atau suatu pencurian dengan kualifikasi ataupun merupakan suatu pencurian dengan unsur-unsur memberatkan. Dengan demikian maka yang diatur dalam Pasal 365 KUHP sesungguhnya hanyalah satu kejahatan, dan bukan dua kejahatan yang terdiri atas kejahatan pencurian dan dengan kejahatan pemakaian kekerasan terhadap orang (Simons, 2005 : 106). Maka sudah jelas bahwa pada hakikatnya, pencurian dengan kekerasan adalah perbuatan yang bertentangan dengan norma agama, moral, kesusilaan maupun hukum, serta membahayakan bagi penghidupan dan kehidupan masyarakat, bangsa dan negara. Ditinjau dari kepentingan nasional, penyelenggaraan pencurian dengan kekerasan merupakan perilaku yang negatif dan merugikan terhadap moral masyarakat.

Pencurian dengan kekerasan merupakan salah satu penyakit masyarakat yang menunggal dengan kejahatan, yang dalam proses sejarah dari generasi ke generasi ternyata kejahatan tersebut merupakan kejahatan yang merugikan dan menyiksa orang lain. Oleh karena itu perlu diupayakan agar masyarakat menjauhi melakukan pencurian dengan kekerasan terhadap orang lain. Pencurian dengan kekerasan dalam perspektif hukum merupakan salah satu tindak pidana (delict) yang meresahkan dan merugikan masyarakat. Perihal tentang yang disebut kekerasan itu Prof. Simons mengatakan : "Onder geweld zal ook hier mogen worden verstan, elke uitoefening van lichamelijke kracht van niet al te geringe betekenid". Yang artinya: "Dapat dimasukkan dalam pengertian kekerasan yakni setiap pemakaian tenaga badan yang tidak terlalu ringan.

Pencurian dengan kekerasan memang suatu kejahatan yang membuat masyarakat menjadi resah. Orang yang melakukan tindak kejahatan tersebut memang dari unsur paksaan terhadap dirinya. Orang tersebut berani melakukan di karenakan ekonomi lemah dan selalu mengharapkan suatu kekayaan yang mengambil diri milik orang lain tanpa terbebani dengan cara bersekutu. Maka dari pihak instansi kepolisian harus lebih ekstra bekerja keras untuk memberantas tindak pidana pencurian yang disertai kekerasan dalam lingkup masyarakat. Secara universal, pesan polisi dalam masyarakat dirumuskan sebagai penegak hukum (law enforcement officers), pemeliharaan ketertiban (order maintenance). Peran tersebut di dalamnya mengandung pula pengertian polisi sebagai pembasmi kejahatan (crime fighters). Namun di dalam negara yang sistem politiknya otoriter, makna peran polisi sebagai alat penegak hukum direduksi menjadi alat kekuasaan. 
Sebagai akibatnya, keberadaan polisi bukannya dekat dan melindungi masyarakat, melainkan sebaliknya berada jauh dari rakyat, dan justru berhadapan dengan rakyatnya. Sementara di negara demokratis, polisi harus transparan dan bukan membela kekuasaan. Oleh karenanya pengawasan terhadap lembaga yang memiliki alat kekerasan ini mesti dilakukan oleh rakyat, lewat badan independen yang menjamin transparansi dan akuntabilitas. Tindakan Polri dalam menanggulangi tindak pidana pencurian dengan kekerasan adalah merupakan bentuk penyelesaian tindak pidana serta bentuk kejahatan yang timbul berdasarkan perbuatan yang tindak pidana pencurian yang disertai dengan kekerasan. Tindakan polri yang di maksud adalah berdasarkan ketentuan Undang-undang kepolisian yaitu Undang-Undang Nomor 2 Tahun 2002 Tentang Kepolisian Negara Republik Indonesia, dengan jelas di uraikan di dalam Undang-undang tersebut tentang ketentuan umum, susunan dan kedudukan kepolisian negara Republik Indonesia, tugas dan wewenang dan seterusnya. Sehingga kepolisian di di nobatkan sebagai penegak hukum.

Tindak pidana pencurian yaitu tindak pidana yang diatur dalam Pasal 365 KUHP sesungguhnya hanyalah satu kejahatan, dan bukan dua kejahatan yang terdiri atas kejahatan pencurian dan kejahatan pemakaian kekerasan terhadap orang. Tindak pidana pencurian yang diatur dalam Pasal 365 KUHP juga merupakan gequalificeerde diefstal atau suatu pencurian dengan kualifikasi ataupun merupakan suatu pencurian dengan unsur-unsur yang memberatkan. Menurut Arrest Hoge Raad arti dari kata yang memberatkan adalah karena di dalam pencurian itu, orang telah memakai kekerasan atau ancaman kekerasan. Penelitian ini untuk mengkaji suatu tindak pidana pencurian yang semakin merebah di masyarakat. Pencurian merupakan tindak pidana yang dapat merugikan orang lain. Salah satunya adalah tindak pidana pencurian dengan kekerasan. Pencurian dengan kekerasan tersebut merupakan pencurian yang dilakukan dengan disertai kekerasan terhadap korbannya dan mengambil barang si korban. Biasanya pencurian ini dilakukan oleh dua orang atau lebih. Pencurian dengan kekerasan biasanya dilakukan dengan cara penodongan, perampasan, penjambretan, perampokan dan pembajakan.

Latar belakang seseorang untuk melakukan tindak pidana pencurian dengan kekerasan diantaranya adalah faktor ekonomi, terbatasnya lapangan pekerjaan, ingin mendapatkan uang dengan mudah, lingkungan dan kesenjangan sosial. Maka sebaiknya semua masyarakat harus bisa bekerja sama dengan kepolisian untuk memberantas tindak pidana pencurian di dalam lingkup masyarakat. Supaya tindak pidana tersebut dapat dicegah dan dapat berkurang.

\section{B. Metodologi Penelitian}

Berkaitan dengan penulisan karya ilmiah ini, penulis menggunakan pendekatan penelitian yuridis empiris yaitu penelitian yang menguji efektifitas hukum dalam pelaksanaannya di lapangan. Penulisan ini menggunakan cara studi lapangan (Empiric Research). Studi lapangan yang dilakukan dalam rencana penelitian ini adalah upaya untuk mencari, menemukan dan mengumpulkan data-data yang bersifat primer. Dalam hal ini penulis akan melakukan usaha untuk memperoleh data-data yang dimaksud dengan cara menyelenggarakan tanya jawab (wawancara) bersama para narasumber diantaranya Kasat Reskrim, Kanit Reskrim dan Penyidik Pembantu di Polres Payakumbuh. Analisis data yang dipergunakan dalam penelitian ini adalah analisis kualitatif dan penarikan kesimpulan dilakukan dengan metode induktif, yaitu 
menguraikan hal-hal yang bersifat khusus lalu menarik kesimpulan yang bersifat umum sesuai dengan permasalahan yang dibahas dalam penelitian.

\section{Hasil dan Pembahasan \\ Peranan Kepolisian dalam Menanggulangi Tindak Pidana Pencurian Dengan Kekerasan Di Wilayah Hukum Polres Payakumbuh.}

Wawancara dengan Kasat Reskrim Polres Payakumbuh AKP Indarmawan,SIK, mengatakan dalam bidang penegakan hukum khususnya yang berkaitan dengan penanganan tindak pidana sebagaimana yang di atur dalam KUHAP dan UndangUndang Nomor 2 Tahun 2002 Tentang Kepolisian Republik Indonesia. Polri sebagai penyidik utama yang menangani setiap kejahatan secara umum dalam rangka menciptakan keamanan dalam Negeri, Pasal 16 Undang- Undang Republik Indonesia Nomor 2 Tahun 2002 Tentang Kepolisian Republik Indonesia, telah menetapkan kewenangan sebagai berikut:

1. Melakukan penangkapan, penahanan, penggeledahan, dan penyitaan;

2. Melarang setiap orang meninggalkan atau memasuki tempat kejadian perkara untuk kepentingan penyidikan;

3. Membawa dan menghadapkan orang kepada penyidik dalam rangka penyidikan;

4. Menyuruh berhenti orang yang dicurigai dan menanyakan serta memeriksa tanda pengenal diri;

5. Melakukan pemeriksaan dan penyitaan surat;

6. Memanggil orang untuk didengar dan diperiksa sebagai tersangka atau saksi;

7. Mendatangkan orang ahli yang diperlukan dalam hubungannya dengan pemeriksaan perkara;

8. Mengadakan penghentian penyidikan;

9. Menyerahkan berkas perkara kepada penuntut umum;

10. Mengajukan permintaan secara langsung kepada pejabat imigrasi yang berwenang di tempat pemeriksaan imigrasi dalam keadaan mendesak atau mendadak untuk mencegah atau menangkal orang yang disangka melakukan tindak pidana;

11. Memberikan petunjuk dan bantuan penyidikan kepada penyidik pegawai negeri sipil serta menerima hasil penyidikan penyidik pegawai negeri sipil untuk diserahkan kepada penuntut umum; dan

12. Mengadakan tindakan lain menurut hukum yang bertanggung jawab, yaitu tindakan penyelidikan dan penyidikan yang dilaksanakan dengan syarat sebagai berikut: a) Tidak bertentangan dengan suatu aturan hukum; b) Selaras dengan kewajiban hukum yang mengharuskan tindakan tersebut dilakukan; c) Harus patut, masuk akal, dan termasuk dalam lingkungan jabatannya; d) Pertimbangan yang layak berdasarkan keadaan yang memaksa; dan e) Menghormati hak asasi manusia.

Berdasarkan wawancara dengan AKP Ilham Indarmawan,SIK untuk peran atau tindakan Polri dalam menanggulangi Tindak pidana pencurian dengan kekerasaan dapat terlihat bahwa dari, tindakan Polres Payakumbuh dalam menangani Tindak Pidana pencurian Dengan kekerasan adalah dengan Menjalankan atau mempertahankan protapnya (Progam Tetap) yaitu: Patroli, Berantai, Jartup, Polmas, Kring Serse, Deteksi dini, penanganan TKP. Hal ini rutin dilakukan oleh Polres Payakumbuh dengan koordinasi yang baik antara kapolsek dari wilayah lain dan divisidivisi yang menangani Tindak Pidana pencurian dengan kekerasan ini. Namun dalam pelaksanaan peranannya yang sesuai dengan aturan belum bisa dilaksanakan secara E-ISSN: 2657-0300 Lembaga Penelitian dan Penerbitan Hasil Penelitian Ensiklopedia $\quad 317$ 
maksimal dikarenakan ada beberapa faktor yang menghambat, selain hal itu juga meningkatnya jumlah pencurian dengan kekerasan, dan ini akan berdampak langsung terhadap kinerja kepolisan dan kepercayaan masyarakat terhadap pihak kepolisan.

Berdasarkan hasil wawancara maka kendala paling besar bagi pihak kepolisian Polres Payakumbuh adalah wilayah kerja yang luas dan kurangnya anggota kepolisian yang bertugas pada wilayah tersebut. Sehingga dalam menjalankan tugas pihak kepolisian Polres Payakumbuh harus mengoptimalkan jumlah yang terbatas untuk menanggulangi wilayah yang cukup luas. Pada Wilayah Payakumbuh penduduknya berasal dari berbagai latar belakang pekerjaan, diantaranya ada yang menjadi buruh dari sebuah perusahaan dan juga ada yang menjadi pedagang. Masyarakat Payakumbuh juga berasal dari berbagai macam-macam suku yang menyatu didalam sebuah wilayah Payakumbuh ini. suku-suku dari masyarakat Payakumbuh antara lain berasl dari suku melayu, minang, batak, aceh, jawa, dan sumatera selatan.

Rata-rata masyarakat Payakumbuh bekerja sebagai buruh kasar dari sebuah perusahaan. Mengingat bahwa wilayah Payakumbuh juga bisa dibilang daerah trans atau daerah yang masyarakatnya datang dari luar kota untuk bekerja sebagai pedagang tertentu. Selain dari faktor wilayah yang luas, kendala lain timbul dikarenakan kurang kendaraaan operasional yang terdapat di Polres Payakumbuh sehingga untuk mencapai wilayah yang cukup jauh dari polsek menjadi sedikit susah karena jumlah kendaraan operasional yang terbatas dan juga medan yang dihadapi cukup berbahaya. Untuk mencapai keseluruhan wilayah di Payakumbuh ini pihak Polres Payakumbuh juga mengalami kendala dari segi waktu berhubung luas wilayah dan medan yang ditempuh.

Selain dari kendala dari pihak kepolisian sendiri, kendala juga timbul dari lapangan bahwa Polres Payakumbuh dalam penyelesaian kasus tindak pidana pencurian dengan kekerasan ini didapatkan keterangan bahwa dalam menanggulangi pencurian dengan kekerasan dihadapkan pada beberapa hambatan atau kendala. Bahwa hambatan ini terjadi dikarenakan setiap terjadi pencurian dengan kekerasan masyarakat lambat atau tidak segera melaporkan kepada kepolisian setempat, karena masyarakat masih berpikiran bahwa akan susah apabila berhubungan denga pihak kepolisian. selain itu dengan adanya laporan dari masyarakat tersebut dan setelah dilakukan identifikasi secara mendalam ternyata tidak ditemukan rangkaian yang nyata dari perbuatan pencurian dengan dengan kekerasan, sehingga menyulitkan pihak kepolisian untuk mengidentifikasi lebih lanjut.

Juga terjadi bahwa laporan yang masuk tersebut setelah dilakukan penelitian lebih lanjut didapati kurangnya bukti baik berupa saksi atau bukti lainya. Kurangnya alat bukti tersebut dikarenakan lambatnya masyarakat untuk segera melaporkan kejahatan sehingga kebanyakan TKP (Tempat Kejadian Perkara) rusak dengan rusaknya TKP mengakibatkan sulit untuk menginfentarisasi sidik jari maupun alat bukti lainnya.Selain itu yang menjadi penyebab hambatan atau kendala yang dihadapi Polres Payakumbuh untuk menanggulangi pencurian dengan kekerasan adalah wilayah di daerah Payakumbuh cukup luas, luasnya daerah wilayah Payakumbuh tidak didukung oleh pihak keamanan yang memadai. Kendala selanjutnya yang dialami oleh pihak kepolisian Polres Payakumbuh adalah setelah dilakukan penyelidikan ditemu fakta bahwa yang menjadi Pelaku dari Tindak Pidana Pencurian denga kekerasan ini merupakan bukan penduduk asli dari Payakumbuh. Dapat dikatakan bahwa yang 
melakukan tinak pidana pencurian dengan kekerasan di wilayah Plsek Payakumbuh adalah orang dari luar daerah yang beroperasi di wilayah hukum Polres Payakumbuh.

\section{Faktor Penghambat Polri Dalam Menanggulangi Tindak Pidana Pencurian Dengan Kekerasan Di Wilayah Hukum Polres Payakumbuh.}

Wawancara dengan Bapak Kanit Reskrim Polres Payakumbuh Bapak Aipda Bachtiar,SH, mengatakan kendala paling besar bagi pihak kepolisian Polres Payakumbuh dalam Menanggulangi Tindak Pidana Pencurian Dengan Kekerasan adalah: 1) Wilayah Hukum Polres Payakumbuh yang luas sehingga dalam menanggulangi Tindak Pidana Pencurian dengan kekerasan sulit untuk ditempuh dengan waktu yang singkat; 2) Kurangnya anggota kepolisian yang bertugas pada wilayah tersebut. Sehingga dalam menjalankan tugas pihak kepolisian Polres Payakumbuh harus mengoptimalkan jumlah yang terbatas untuk menanggulangi wilayah yang cukup luas; 3) Kurangnya kendaraaan operasional yang terdapat di Polres Payakumbuh sehingga untuk mencapai wilayah yang cukup jauh dari polsek menjadi sedikit susah karena jumlah kendaraan operasional yang terbatas dan juga medan yang dihadapi cukup berbahaya. Untuk mencapai keseluruhan wilayah di Polres Payakumbuh juga mengalami kendala dari segi waktu berhubung luas wilayah dan medan yang ditempuh; dan 4) Masyarakat belum menerima sepenuhnya apa yang diarahkan bhabinkamtibmas.

Dalam hal ini Polri dalam menanggulangi tindak pidana pencurian dengan kekerasan ini dilihat secara umum ada beberapa faktor yang menjadi penghambat yaitu:

a. Faktor Penegak Hukum. Dari kasus yang telah ada di karenakan jumlah personil di Polres Payakumbuh yang kekurangan personil membuat tidak efektif pekerjaan dibidangnya masing-masing. Sering kali dari bagian terutama Reserse akan merangkap tugas sebagai bagian intelejen untuk melakukan penyelidikan, begitupun dengan bagian fungsi yang lain, memaparkan akan pentingnya penegak hukum, melihat penegakan hukum yang ada pada saat ini memang sedikit memprihatinkan karena tidak jarang dari penegak hukum lah yang ikut campur dalam bidang kotor seperti memberikan izin untuk kegiatan negatif yang dilarang seperti judi dan tempat hiburan, dalam kebanyakan kasus yang terungkap para pelaku tindak pidana memiliki seseorang dibelakangnya dari salah seorang penegak hukum untuk melindungi prakteknya. Hal itulah yang harusnya ditindak tegas dan harus diluruskan agar para penegak hukum bisa sejalan dengan perturan yang ada. Dalam melakukan pekerjaan sudah selayaknya para penegak hukum mengabdikan dirinya kepada bangsa dan negara demi kepentingan rakyat. Tindakan tegas harus diberlakukan kepada para penegak hukum yang kotor agar timbul kemanan dan ketertiban bagi masyarakat.

b. Faktor Sarana dan Fasilitas. Untuk luas wilayah yang ada di Polres Payakumbuh memang terjadi ketidak seimbangan antara jumlah personil di Polres Payakumbuh dengan luas wilayah Payakumbuh. Sering kali dari pihak kepolisian susah untuk menjangkau daerah pedesaan yang terutama daerah yang di pedalaman untuk melakukan patroli, penjagaan dan razia. Hal tersebut sering dimanfaatkan oleh para pelaku kejahatan untuk melancarkan aksinya. Untuk suatu ruang lingkup Polsek di Payakumbuh seharusnya minimal memiliki personil 60 anggota yang terbagi dalam setiap bagian akan tetapi pada saat ini di Polres Payakumbuh hanya meiliki 36 personil. Sarana berupa kendaraan juga tidak menunjang dikarenakan kondisi jalanan yang rusak di sebagian wilayah di 
Polres Payakumbuh sehingga susah untuk di tempuh karena kurangnya armada transportasi. Hal ini juga akan penghambat proses dalam penyelidik dan penyidikan dalam setiap pengusutan suatu kasus. Dalam suatu kondisi wilayah yang memiliki medan yang luas dan infrastruktur jalan yang memiliki medan yang jelek haruslah dibutuhkan sarana dan prasarana yang memadai, karena dengan begitu maka akan mempermudah suatu penegakan hukum yang akan dilakukan pihak kepolisian.

c. Faktor Masyarakat. Kesadaran hukum yang dimaksud berpangkal pada perasaan setiap individu yaitu bagaimana seharusnya perasaan hukum itu. Hal ini sesuai dengan pendapat Stammler yang menyatakan bahwa law cleary is volition sehingga penerapan hukum terindikasi dari kemauan masyarakat untuk melakukanya. Dapat dikatakan bahwa budaya hukum akan mempengaruhi penolakan dan penerimaan masyarakat terhadap suatu peraturan hukum, hal ini penting diperhatikan karena tanpa masyarakat hukum akan kehilangan kewibawaan mengenai peraturanya. Dari hasil wawancara menjelaskan bahwa dalam penanggulanagan tindak pidana pencurian dengan kekerasan dari pihak kepolisian sangat membutuhkan kerjasama dengan masyarakat. Masyarakat dalam hal ini bisa berperan sebagai pelapor yang baik dan bersedia membantu proses penyelidikan dan penyidikan ketika ada kejadian yang bersangkutan dengan dirinya, hal tersebut bisa sebagai saksi atau juga sebagai korban bahkan pelaku. Masyarakat sangat penting memiliki kesadaran dan kewaspadaan tentang bahaya pencurian dengan kekerasan. Masyarakat adalah faktor yang besar pengaruhnya dalam suatu penegakan hukum, jika kesadaran masyarakat akan hukum sudah tinggi maka akan sangat mudah bagi pihak kepolisian untuk menangani perkara. Jadi sangat dibutuhkan kerja sama yang baik diantara kedua belah pihak ini.

d. Faktor Kebudayaan. Untuk wilayah Payakumbuh terutama di daerah pusat yaitu Unit Dua memiliki pertumbuhan ekonomi yang sangat tinggi. Di lingkungan tersebut memiliki berbagai perbedaan dalam hal, agama, suku, bahasa dan sebagainya. Pertumbuhan ekonomilah yang menjadikan hal tersebut terus berkembang dimana dari para perantau akan banyak yang mencari pekerjaan di Payakumbuh. Kondisi ini yang dimanfaatkan oleh para penduduk setempat untuk mendirikan bangunan seperti rumah, atau kos-kosan yang nantinya akan dikontrakan kepada para pendatang tersebut. Kebudayaan yang kurang baik yang terjadi selama ini dilingkungan tersebut adalah membiarkan para tamu yang untuk singgah tersebut tanpa memberi laporan kepada ketua RT atau RW nya masing-masing. Kebiasaan yang meremehkan atas bahaya terhadap orang asing seringkali menjadi modus dari para pelaku tindak pidana pencurian dengn kekerasan untuk memanfaatkan situasi ini. Pelaku pencurian akan sangat leluasa untuk berkeliling di daerah tersebut dengan keadaan lingkungan yang tidak memperhatikaanya dimana ketika mereka menganggap situasi itu sudah pas dan saat orang-orang lengah meninggalkan kendaraan sembarangan tanpa kunci tambahan, maka pada saat itulah para pelaku melancarkan aksi pencurian.

Situasi yang terjadi kepada daerah dengan perekonomian yang maju. Hal tersebut akan memicu banyaknya orang untuk berdatangan tidak menutup kemungkinan bahwa banyak pula dari sekian orang yang datang memiliki niat yang buruk, di Daerah Payakumbuh sudah banyak daerah yang menjadi pusat para pelaku kejahatan tindak 
pidana pencurian dengan kekerasan. Akan tetapi dengan berkembangnya zaman di era pada saat ini, kebudayaan justru akan banyak yang menyalahgunakanya. Sikap yang tanggap dan bisa menyesuaikan diri terhadap lingkungan sangatlah diharapkan untuk situasi ini karena hal tersebut akan menjaga diri dan harta benda kita dari perbuatan yang tidak kita inginkan.

\section{Upaya Yang Dilakukan Oleh Polri Dalam Mengatasi Faktor Penghambat dalam Menanggulangi Tindak Pidana Pencurian Dengan Kekerasan Di Wilayah Hukum Polres Payakumbuh.}

Wawancara dengan Penyidik Pembantu Polres Payakumbuh Briptu Khut Silalahi bahwa, Polres Payakumbuh juga sudah melakukan upaya-upaya penanggulangan yang dilakukan pihak Kepolisian terhadap maraknya aksi-aksi pencurian dengan kekerasan beberapa tahun terakhir. Upaya-upaya ini memang sangatlah penting karena pada hakekatnya upaya-upaya tersebut bukanlah menjadi kewajiban aparat penegak hukum saja akan tetapi juga merupakan kewajiban masyarakat. Beberapa upaya penanggulangan terhadap maraknya aksi-aksi pencurian dengan kekerasan yang dilakukan Polres Payakumbuh adalah sebagai berikut: Pre-Emtif, Upaya Preventif Dan Upaya Represif.

Adapun upaya yang dilakukan oleh polri dalam mengatasi faktor penghambat dalam menanggulangi tindak pidana pencurian dengan kekerasan di wilayah hukum Polres Payakumbuh adalah:

1. Dikarenakan wilayah hukum yang luas sehingga untuk menanggulangi tindak pidana pencurian dengan kekerasan di wilayah hukum Polres Payakumbuh sulit untuk dilakukan namun diharapkan adanya penambahan anggota kepolisian yang bertugas pada wilayah hukum Polres Payakumbuh tersebut.

2. Diharapkan adanya penambahan kendaraaan operasional yang terdapat di Polres Payakumbuh sehingga untuk mencapai wilayah yang cukup jauh dari polsek menjadi mudah.

3. Melakukan Sosialisasi tentang pencegahan perbuatan-perbuatan tindak pidana pencurian dengan kekerasan oleh bhabinkamtibmas antara lain: a) Setiap hari sabtu dan minggu selalu memberikan himbauan kepada pegunjung pasar, agen, dan ojek; b) Hari selasa penyuluhan kepada sekolah SMP dan SMA; c) Kamis malam dan Jum'at melakukan penyuluhan atau menyampaikan pesan Kamtibmas di masjid; dan d) Setiap hari rabu sore melakukan pembinaan/bimbingan ke generasi muda tentang pencegahan terjadinya gangguan Kamtibmas.

Beberapa upaya penanggulangan terhadap maraknya aksi-aksi pencurian dengan kekerasan yang dilakukan Polres Payakumbuh adalah sebagai berikut: Pre-emtif. Yang dimaksud dengan upaya pre-emtif disini adalah upaya-upaya awal yang dilakukan oleh pihak kepolisian untuk mencegah terjadinya tindak pidana.Usaha-usaha yang dilakukan dalam penanggulan kejahatan secara pre-emtif menanamkan nilainilai/norma-norma yang baik sehingga norma- norma tersebut terinternalisai dalam diri seseorang. Meskipun ada kesempatan untuk melakukan pelanggaran/kejahatan tapi tidak ada niatnya untuk melakukan hal tersebut maka tidak akan terjadi kejahatan. Jadi dalam usaha pre-emtif faktor niat menjadi hilang meskipun ada kesempatan. Cara pencegahan ini berasal dari teori NKK, yaitu: Niat + Kesempatan terjadinya kejahatan. Contohnya, ditengah malam pada saat lampu merah lalu lintas menyala maka pengemudi itu akan berhenti dan mematuhi aturan lalu lintas tersebut meskipun pada waktu itu tidak ada polisi yang berjaga. Hal ini selalu terjadi dibanyak Negara seperti 
Singapura, Sydney, dan kota besar lainnya didunia. Jad idalam upaya pre-emtif faktor "NIAT" tidak terjadi.

Upaya Preventif. Upaya-upaya preventif ini adalah merupakan tindak lanjut dari upaya pre-emtif yang masih dalam tataran pencegahan sebelum terjadinya kejahatan. Dalam upaya preventif ditekankan adalah menghilangkan kesempatan untuk dilakukannya. Contoh ada orang ingin mencuri motor tetapi kesempatan itu dihilangkan karena motor-motor yang ada ditempatkan ditempat penitipan motor, dengan demikian kesempatan menjadi dan tidak terjadi kejahatan. Jadi dalam upaya preventif kesempatan ditutup.

Upaya ini juga bisa disebut sebagai upaya mencegah terjadinya kejahatan untuk pertama kalinya. Upaya pencegahan yang dilakukan untuk mengurangi kejahatan. Upaya pencegahan yang dilakukan untuk mengurangi kejahatan dibagi menjadi dua yaitu: 1) Moralistik, dilakukan dengan cara membina mental spiritual yang bisa dilakukan oleh paraulama, para pendidik, dan lain-lain; dan 2) Abolisionistik, adalah dengan cara penanggulangan bersifat konsepsional yang harus direncanakan dengan dasar penelitian kriminologi, dan menggali sebab-musababnya dari berbagai faktor yang berhubungan ( Soejono Dirdjosisworo, 1984 : 19).

Dari hasil wawancara adapun upaya-upaya pencegahan yang dilakukan oleh Polres Payakumbuh adalah dengan seringnya mereka membuat spanduk-spanduk yang berisi himbauan terhadap masyarakat agar selalu ingat akan keamanan diri, harta benda yang dimiliki. Himbauan tersebut banyak pula dipasang di sudut-sudut jalan sehingga mudah untuk dibaca masyarakat sehingga mereka mudah dan selalu mengingatnya, meningkatkan penyuluhan sambang dan himbauan kepada masyarakat dikalangan pasar dan sekolah.

Unit Sabhara Polres Payakumbuh juga menjelaskan langkah-langkah preventif yang dilakukan untuk menanggulangi tindak pidana pencurian dengan kekerasan ini adlaah sebagai berikut:

a) Unit Sabhara Polsek Bertugas sebagai pengemban tugas preventif (pencegahan) dengan melakukan tugas pokok Turjawali: Pengaturan, Penjagaan, Pengawalan, Patroli.

b) Turjawali dilakukan untuk mencegah terjadinya pertemuan antara niat dan kesempatan (niat+kesempatan=tindak pidana) atau singkatan $\mathrm{N}+\mathrm{K}=\mathrm{TP}$.

c) Pengaturan Sabhara dilakukan saat strong point pagi hari untuk melancarkan arus jalan di persimpangan.

d) Penjagaan dilakukan di polsek dan rumah-rumah pejabat ataupun perusahaan.

e) Pengawalan adalah tugas Preventif yang dilakukan berupa bentuk: 1) Pengawalan Orang; 2) Pengawalan dokument/surat-surat berharga; dan 3) Pengawalan uang milik negara, perusahaan, dan perorangan.

f) Patroli dilakukan untuk mencegah terjadinya tindak Pidan Penccurian dengan kekerasan ke tempat rawan terjadinya tindak pidana pencurian dengan kekerasan seperti perusahaan dan tempat-tempat lain yang rawan terjadinya tindak pidana pencurian dengan kekerasan

Beberapa langkah preventif yang dilakukan untuk mencegah terjadinya tindak pidana pencurian dengan kekerasan. Diantaranya adalah sebagai berikut:

1. Pengaturan di persimpangan pada pagi hari dan jam pulang anak sekolah atau jam pulang kantor. 
2. Penjagaan sewaktu hari pasar atau kegiatan masyarakat lainnya dilakukan PAM dan pengamanan di pos-pos sementara.

3. Pengawalan petugas unit Sabhara Polres Payakumbuh siap memberikan pengawalan terhadap orang, barang, dan surat-surat berharga, dokumen dan uang.

4. Patroli dilakukan dengan berbagai kegiatan patroli sebagai berikut: Patroli jalan kaki, Patroli bersepeda, Patroli bermotor roda 2, dan Patroli bermotor roda 4.

5. Adapun rute patroli dilakukan ke tempat-tempat ramai kegiatan masyarakat dan ke tempat-tempat rawan terjadinya tindak pidana pencurian dengan kekerasan.

Untuk menanggulangi terjadinya tindak pidana pencurian dengan kekerasan maka unit Sabhara Polres Payakumbuh meningkatkan kegiatan pencegahan/Preventif di Kepolisian sebagai berikut: 1) Patroli jalan kaki ke dalam pasar; 2) Patroli bersepeda sepanjang perkantoran; dan 3) Patroli roda 2 ke Lokasi-lokasi rawan terjadinya tindak pidana pencurian dengan kekerasan. Pihak Polres Payakumbuh juga sering mengadakan penyuluhan kepada masyarakat yang isi dari penyuluhan tersebut adalah memberikan arti penting menjaga keamanan lingkungan mereka sendiri dan juga dengan cara pemulisian sipil supaya masyarakat menjadi polisi terhadap dirinya sendiri, dengan hal semacam itu maka setiap kejahatan yang akan terjadi mudah terdeteksi oleh masyarakat secara dini, karena bagaimanapun personel Polri sangat terbatas jika dibandingkan dengan masyarakat yang ada diwilayah Polres Payakumbuh sehingga akan lebih efektif jika pengawasan juga dilakukan oleh masyarakat secara aktif. Pihak kepolisian juga melakukan pendataan terhadap residivis-residivis yang baru keluar dari lembaga pemasyarakatan dimana pendataan ini berguna apabila seorang residivis yang melakukan kejahatan lebih mudah di identifikasi dan segera dilakukan penangkapan.

Upaya Represif. Upaya ini dilakukan pada saat telah terjadi tindak pidana/kejahatan yang tindakan berupa penegakan hukum (law enforcement) dengan menjatuhkan hukuman.Upaya represif adalah suatu upaya penanggulangan kejahatan secara konsepsional yang ditempuh setelah terjadinya kejahatan. Penanggulangan dengan upaya represif untuk menindak para pelaku sesuai dengan perbuatannya serta memperbaikinya kembali agar mereka sadar bahwa perbuatan yang dilakukannya adalah perbuatan melanggar hukum dan merugikan masyarakat, sehingga tidak mengulanginya dan orang lain juga tidak akan melakukannya mengingat sanksi yang ditanggungnya sangat berat. Dalam membahas sistem represif, tentunya tidak lepas dari sistem pidana kita, dimana dalam sistem peradilan pidana paling sedikit terdapat 5 (lima) sub-sistem yaitu sub-sistem kehakiman, kejaksaan, kepolisian, pemasyarakatan, dan kepengacaraan. Yang merupakan suatu keseluruh- an dalam terangkai dan berhubungan secara fungsional. Dalam penanggulangan secara represif cara-cara yang ditempuh bukan lagi pada tahap bagaimana mencegah terjadinya suatu kejahatan tetapi bagaimana menanggulangi atau mencari solusi atas kejahatan yang sudah terjadi. Atas dasar itu kemudian, langkah-langkah yang biasa ditempuh cenderung bagaimana menindak tegas pelaku kejahatan atau bagaimana memberikan efek jera terhadap pelaku kejahatan.

Penanganan represif ini dilakukan oleh aparat penegak hukum yakni kepolisian, kejaksaan, dan pengadilan. Dalam rangka bekerjanya system peradilan pidana untuk menanggulangi kejahatan, kepenjaraan ataupun lembaga permasyarakatan adalah sebagai lembaga koreksi dalam penanggulangan kriminalitas (Soejono Dirdjosisworo, $1994: 157)$ 


\section{Penutup}

Berdasarkan pembahasan tersebut di atas, maka penulis telah menarik kesimpulan terkait kedua permasalahan hukum bangunan di atas air sebagai berikut: Peranan kepolisian dalam menangani Tindak Pidana pencurian Dengan kekerasan adalah dengan Menjalankan atau mempertahankan protapnya (Progam Tetap) yaitu: Patroli, Berantai, Jartup, Polmas, Kring Serse, Deteksi dini, penanganan TKP. Hal ini rutin dilakukan oleh Polres Payakumbuh dengan koordinasi yang baik antara kapolsek dari wilayah lain dan divisi-divisi yang menangani Tindak Pidana pencurian dengan kekerasan ini. Kendala yang dihadapi Polres Payakumbuh untuk menanggulangi pencurian dengan kekerasan pada umumnya setiap terjadi pencurian dengan kekerasan masyarakat lambat atau tidak segera melaporkan kepada kepolisian setempat, mengingat kurang cepatnya laporan, sehingga kebanyakan tempat kejadian perkara (TKP) rusak sehingga menyulitkan tim TKP untuk menginventarisasi sidik jari latar maupun alat bukti langsung. Wilayah hukum daerah Polres Payakumbuh yang cukup luas, luasnya daerah wilayah tidak didukung oleh pihak keamanan yang memadai dan juga kendaraan operasional yang mencukupi. Dan juga ada beberapa medan yang cukup sulit ditemuh sehingga kurangnya sosialisasi dan pengamanan pada daerah tersebut. Adapun yang harus dilakukan untuk memaksimalkan upaya-upaya tersebut antara lain: Melakukan Sosialisasi tentang pencegahan perbuatan-perbuatan tindak pidana (Khususnya Tindak Pidana Pencurian dengan kekerasan), Juga Menyampaikan kepada warga baik ditempat umum atau ditempat ibadah tentang seringnya terjadi pencurian dengan kekerasan

\section{Daftar Pustaka}

C. S.T. Kansil, 1989, Pengantar Ilmu Hukum dan Tata Hukum Indonesia, Cet Ke-8, Balai Pustaka, Jakarta

Simons, 2005, Leerboek van het Nederlandse Strafrecht II, PT Raja Grafindo Persada, Jakarta

Pudi Rahardi, 2010, Hukum Kepolisian (Profesionalisme dan Reformasi Polri), Laksbang Mediatama, Surabaya.

Ninik Widiyanti, Yulius Waskita, 1987, Kejahatan Dalam Masyarakat Dan Pencegahannya, Penerbit Bina Aksara Jakarta.

Soebroto Brotodiredjo dalam R. Abdussalam. 1997. Penegak Hukum Di Lapangan Oleh Polri. Dinas Hukum Polri, Jakarta.

Sadjijono,2010, Memahami Hukum Kepolisian, Laksbang Persindo, Yogyakarta,

Soejono Dirdjosisworo, 1984, Ruang Lingkup Kriminologi, Penerbit Remaja Karya, Bandung

Soejono Dirdjosisworo, 1994, Synopsis Kriminologi Indonesia, Mandar Maju, Bandung

Undang-Undang Dasar Republik Indonesia 1945

Kitab Undang-Undang Hukum Pidana

Undang-Undang Nomor 8 Tahun 1981 Tentang Hukum Acara Pidana

Undang-Undang Nomor 2 Tahun 2002 Tentang Kepolisian Negara Republik Indonesia 